\title{
Heterotrinuclear Complexes of the Platinum Group Metals with 2,2'-Biimidazole as a Bridging Ligand
}

\author{
Andrey Mayboroda, ${ }^{[a]}$ Peter Comba, ${ }^{*[a]}$ Hans Pritzkow, ${ }^{[a]}$ Gerd Rheinwald, ${ }^{[b]}$ \\ Heinrich Lang, ${ }^{[b]}$ and Gerard van Koten ${ }^{[c]}$
}

Keywords: Osmium / Platinum / Palladium / Heterometallic complexes / Cyclic voltammetry / Hydrogenation

The novel trinuclear complexes $\left[\left(\mathrm{Pt}_{\{} \mathrm{C}_{6} \mathrm{H}_{3}\left(\mathrm{CH}_{2} \mathrm{NMe}_{2}\right.\right.\right.$ $\left.\left.\left.2,6)_{2}\right\}\right)_{2}(\mu-\mathrm{Hbiim})_{2} \mathrm{Os}\left(\mathrm{O}=\mathrm{PPh}_{3}\right)_{2}\right]\left(\mathrm{NO}_{3}\right)\left(\mathrm{SO}_{3} \mathrm{CF}_{3}\right)_{2}\left[\mathrm{C}_{6} \mathrm{H}_{3}-\right.$ $\left(\mathrm{CH}_{2} \mathrm{NMe}_{2}-2,6\right)_{2}=$ pincer ligand, $\mathrm{H}_{2}$ biim $=2,2^{\prime}$-biimidazole $]$ and $\left[(\mathrm{PdL})_{2}(\mu \text {-biim })_{2} \mathrm{Os}\left(\mathrm{O}=\mathrm{PPh}_{3}\right)_{2}\right]\left(\mathrm{NO}_{3}\right)_{3}(\mathrm{~L}=$ cod, 1,5-cyclooctadiene or $\mathrm{L}=\mathrm{en}$, ethylene-1,2-diamine) were prepared by the reaction of the mononuclear complex $\left[\mathrm{Os}\left(\mathrm{H}_{2} \text { biim }\right)_{2}\right.$ $\left.\left(\mathrm{O}=\mathrm{PPh}_{3}\right)_{2}\right]\left(\mathrm{NO}_{3}\right)_{3}$ with $\left[\mathrm{Pt}\left\{\mathrm{C}_{6} \mathrm{H}_{3}\left(\mathrm{CH}_{2} \mathrm{NMe}_{2}-2,6\right)_{2}\right\}\right]\left(\mathrm{SO}_{3} \mathrm{CF}_{3}\right)$, or with $\operatorname{PdL}\left(\mathrm{NO}_{3}\right)_{2}(\mathrm{~L}=\operatorname{cod}$ or $\mathrm{L}=\mathrm{en})$, in the presence of $\mathrm{a}$ base. The exchange reaction between [Os $(\mathrm{Hbiim})_{2}(\mathrm{O}=$ $\left.\left.\mathrm{PPh}_{3}\right)_{2}\right]\left(\mathrm{NO}_{3}\right)_{3}$ and $\left[\mathrm{Me}_{2} \mathrm{NH}_{2}\right]\left[\mathrm{RhCl}_{4}\left(\mathrm{NHMe}_{2}\right)\right]$ led to the formation of $\left[\mathrm{Os}(\mathrm{Hbiim})_{2}\left(\mathrm{O}=\mathrm{PPh}_{3}\right)_{2}\right]\left[\mathrm{RhCl}_{4}\left(\mathrm{NHMe}_{2}\right)\right]$. The solid-state structures of $\left[\mathrm{Os}(\mathrm{Hbiim})_{2}\left(\mathrm{O}=\mathrm{PPh}_{3}\right)_{2}\right]\left[\mathrm{RhCl}_{4}\right.$ $\left.\left(\mathrm{NHMe}_{2}\right)\right]$ and $\left[\left(\mathrm{Pt}\left\{\mathrm{C}_{6} \mathrm{H}_{3}\left(\mathrm{CH}_{2} \mathrm{NMe}_{2}-2,6\right)_{2}\right\}\right)_{2}(\mu-\mathrm{Hbiim})_{2} \mathrm{Os}(\mathrm{O}=\right.$ $\left.\left.\mathrm{PPh}_{3}\right)_{2}\right]\left(\mathrm{NO}_{3}\right)\left(\mathrm{SO}_{3} \mathrm{CF}_{3}\right)_{2} \cdot 4 \mathrm{H}_{2} \mathrm{O}$ were determined by singlecrystal X-ray diffraction. The crystals of $\left[\mathrm{Os}(\mathrm{Hbiim})_{2}(\mathrm{O}=\right.$ $\left.\left.\mathrm{PPh}_{3}\right)_{2}\right]\left[\mathrm{RhCl}_{4}\left(\mathrm{NHMe}_{2}\right)\right]$ are triclinic with a space group $P \overline{1}$,

\section{Introduction}

Oligonuclear complexes in which the transition-metal centers are bridged by $\pi$-conjugated ligands have attracted much attention as model compounds for the study of cooperative effects in, for example, homogeneous catalysis. ${ }^{[1]}$ Mechanisms have been postulated which involve more than one catalytically active metal center within the oligometallic array. ${ }^{[2]}$ Generally, however, only one of the metal centers plays a dominant role in the catalytic cycle, while the other(s) influence the molecular architecture and support the catalytically active center as a donor or acceptor of electron density. An enhancement of the reactivity results from changes in the ligand field or from intramolecular electronic communication between the transition-metal centers. ${ }^{[\mathrm{b}]}$

\footnotetext{
[a] Anorganisch-Chemisches Institut, Universität Heidelberg, Im Neuenheimer Feld 270, 69120 Heidelberg, Germany E-mail: comba@akcomba.oci.uni-heidelberg.de

[b] Technische Universität Chemnitz, Fakultät für Naturwissenschaften, Institut für Chemie, Lehrstuhl Anorganische Chemie,

Straße der Nationen 62, 09111 Chemnitz, Germany

[c] Debye Institute, Department of Metal-Mediated Synthesis, Utrecht University,

Padualaan 8, $3584 \mathrm{CH}$ Utrecht, The Netherlands

Supporting information for this article is available on the WWW under http://www.eurjic.org or from the author.
}

with $a=10.4293(5), b=10.6365(6), c=13.0287(7) \AA, \beta=$ 91.6840(10), $\gamma=109.8540(10)^{\circ}, V=1316.14(12) \AA^{3}, Z=1$. The crystals of the complex $\left[\left(\mathrm{Pt}_{2} \mathrm{C}_{6} \mathrm{H}_{3}\left(\mathrm{CH}_{2} \mathrm{NMe}_{2}-2,6\right)_{2}\right\}\right)_{2}(\mu-$ $\left.\mathrm{Hbiim})_{2} \mathrm{Os}\left(\mathrm{O}=\mathrm{PPh}_{3}\right)_{2}\right]\left(\mathrm{NO}_{3}\right)\left(\mathrm{SO}_{3} \mathrm{CF}_{3}\right)_{2} \cdot 4 \mathrm{H}_{2} \mathrm{O}$ are triclinic with a space group $P \overline{1}$, with $a=12.604(3), b=13.471(3), c=$ 14.347(3) $\AA, \beta=77.530(5), \gamma=66.613(4)^{\circ}, V=2005.6(7) \AA^{3}$, $Z=1$. Deprotonation of $2,2^{\prime}$-biimidazole in the mononuclear osmium complex, followed by coordination to an additional transition metal fragment leads to a modification of the ligand field and a variation of the redox properties of the Os ${ }^{\mathrm{III}}$ center. $\left[\{\mathrm{Pd}(\mathrm{cod})\}_{2}(\mu \text {-biim })_{2} \mathrm{Os}\left(\mathrm{O}=\mathrm{PPh}_{3}\right)_{2}\right]\left(\mathrm{NO}_{3}\right)_{3}$ shows significant catalytic activity towards hydrogenation of terminal and cyclic alkenes.

(C) Wiley-VCH Verlag GmbH \& Co. KGaA, 69451 Weinheim, Germany, 2003)
Much attention has been focused on the metal-binding ability of the ligand 2,2'-biimidazole $\left(\mathrm{H}_{2}\right.$ biim $)$ and its derivatives. ${ }^{[3-9]}$ Anionic moieties, e.g. $\mathrm{Hbiim}^{-}$and biim $^{2-}$, have successfully been used as bridging ligands for the synthesis of homo- and heterometallic oligonuclear complexes. Dinuclear 2,2'-biimidazolate complexes of $\mathrm{Rh}^{\mathrm{I}},{ }^{[3]} \mathrm{Ir}^{\mathrm{I}},{ }^{[3]}$ $\mathrm{Cu}^{\mathrm{II}}{ }^{[4]} \mathrm{Pd}^{\mathrm{II}}{ }_{,}{ }^{[5,6]} \mathrm{Ru}^{\mathrm{II}},{ }^{[7]} \mathrm{Ru}^{\mathrm{II}}-\mathrm{Os}^{\mathrm{II}}{ }^{[8]}$ and $\mathrm{Ru}^{\mathrm{II}}-\mathrm{Rh}^{\mathrm{I}}{ }^{[9]}$ have been prepared and characterized. An example of a trinuclear heterometallic species of the structural type $\mathbf{A}$ is $\left[\left\{\mathrm{Au}\left(\mathrm{PPh}_{3}\right)\right\}_{2}(\mu\right.$-bbzim $\left.) \mathrm{Rh}(\mathrm{cod})\right]\left(\mathrm{ClO}_{4}\right) \quad\left(\right.$ bbzim $=2,2^{\prime}$-bibenzimidazole). ${ }^{[9]}$ However, so far there are no examples of trinuclear complexes of types $\mathbf{B}$ and $\mathbf{C}$ (Figure 1).

Here, we report on the synthesis and characterization of the $\mathrm{Pt}^{\mathrm{II}}-\mathrm{Os}^{\mathrm{III}}-\mathrm{Pt}^{\mathrm{II}}$ and $\mathrm{Pd}^{\mathrm{II}}-\mathrm{Os}^{\mathrm{III}}-\mathrm{Pd}^{\mathrm{II}}$ complexes, with 2,2' -biimidazolate $\left(\mathrm{Hbiim}^{-}\right.$, biim $\left.^{2-}\right)$ as the bridging ligands (structural types $\mathbf{B}$ and $\mathbf{C}$ ). The solid-state structures of $\left[\mathrm{Os}(\mathrm{Hbiim})_{2}\left(\mathrm{O}=\mathrm{PPh}_{3}\right)_{2}\right]\left[\mathrm{RhCl}_{4}\left\{\mathrm{NH}\left(\mathrm{CH}_{3}\right)_{2}\right\}_{2}\right] \quad$ (2b) and $\left[\left(\mathrm{Pt}\left\{\mathrm{C}_{6} \mathrm{H}_{3}\left(\mathrm{CH}_{2} \mathrm{NMe}_{2}-2,6\right)_{2}\right\}\right)_{2}(\mu-\mathrm{Hbiim})_{2} \mathrm{Os}\left(\mathrm{O}=\mathrm{PPh}_{3}\right)_{2}\right]-$ $\left(\mathrm{NO}_{3}\right)\left(\mathrm{SO}_{3} \mathrm{CF}_{3}\right)_{2} \cdot 4 \mathrm{H}_{2} \mathrm{O}(7)$ are reported (for the numbering of the complexes, see Scheme 1, cod =1,5-cyclooctadiene, en $=$ ethylene-1,2-diamine). The electrochemical behavior of compounds 7-9 was studied, using cyclic voltammetry, and the catalytic activity of 7-9, in the homogeneous hydrogenation of 1-hexene and cyclohexene, is also reported. 


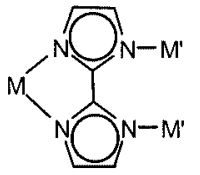

A

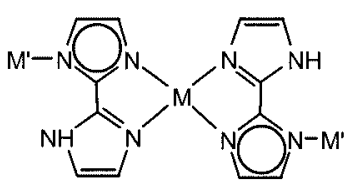

B

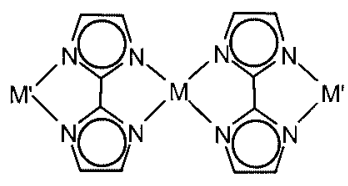

C
Figure 1. Type $\mathbf{A}-\mathbf{C}$ trinuclear complexes with different binding modes between $2,2^{\prime}$-biimidazole and the transition metal centers $\mathrm{M}$ and $\mathrm{M}^{\prime}$

\section{Results and Discussion}

\section{Synthesis and Spectroscopy}

The mononuclear osmium(III) complex $\left[\mathrm{Os}\left(\mathrm{H}_{2} \text { biim }\right)_{2}(\mathrm{O}=\right.$ $\left.\left.\mathrm{PPh}_{3}\right)_{2}\right]\left(\mathrm{NO}_{3}\right)_{3}(\mathbf{1}),{ }^{[10]}$ was used as a starting material in the synthesis of the trimetallic $\mathrm{OsPt}_{2}$ and $\mathrm{OsPd}_{2}$ complexes 7-9. Complex $\mathbf{1}$ is a polybasic acid and was successfully deprotonated by $\mathrm{KOH}$, affording $\left[\mathrm{Os}(\mathrm{Hbiim})_{2}(\mathrm{O}=\right.$ $\left.\left.\mathrm{PPh}_{3}\right)_{2}\right]\left(\mathrm{NO}_{3}\right)$ (2), ${ }^{[10]}$ and $\left[\mathrm{Os}(\operatorname{biim})_{2}\left(\mathrm{O}=\mathrm{PPh}_{3}\right)_{2}\right]^{-}$(3, not isolated as a solid). Complexes $\mathbf{2}$ and $\mathbf{3}$ are reactive building blocks ("metal complex as the ligand"), which smoothly reacted with various transition-metal complexes, producing the trimetallic compounds 7-9 in high yields (Scheme 1). After appropriate workup, complexes 7-9 were isolated as red $(7)$ or dark green $(\mathbf{8}, 9)$ air-stable solids, which gradually decompose at temperatures higher than $150{ }^{\circ} \mathrm{C}$. They are insoluble in tetrahydrofuran, acetone, diethyl ether and aromatic hydrocarbons, only moderately soluble in methanol and dichloromethane, but very soluble in a mixture of these solvents, e.g., in $80 \%$ of dichloromethane and $20 \%$ of methanol.

We were also interested in the structural properties of mononuclear osmium(III) complexes with a partially deprotonated 2,2'-biimidazolate ligand. Attempts to crystallize $\left[\mathrm{Os}(\mathrm{Hbiim})_{2}\left(\mathrm{O}=\mathrm{PPh}_{3}\right)_{2}\right]\left(\mathrm{NO}_{3}\right)$ (2a) from dichloromethane/ methanol were unsuccessful. However, in the presence of the rhodium(III) salt $\left[\mathrm{Me}_{2} \mathrm{NH}_{2}\right]\left[\mathrm{RhCl}_{4}\left\{\mathrm{NH}\left(\mathrm{CH}_{3}\right)_{2}\right\}_{2}\right]$ (10) single crystals of $\left[\mathrm{Os}(\mathrm{Hbiim})_{2}\left(\mathrm{O}=\mathrm{PPh}_{3}\right)_{2}\right]\left[\mathrm{RhCl}_{4}(\mathrm{NH}\right.$ $\left.\left(\mathrm{CH}_{3}\right)_{2}\right)_{2}$ ] (2b), suitable for X-ray structure determination, could be obtained (see below).

The UV/Vis spectra of 7-9 have an absorbance maximum at approx. $350 \mathrm{~nm}$, which can be assigned to a metalto-ligand charge-transfer transition ffor comparison, the parent complex $\left[\mathrm{Os}\left(\mathrm{H}_{2} \text { biim }\right)_{2}\left(\mathrm{O}=\mathrm{PPh}_{3}\right)_{2}\right]\left(\mathrm{NO}_{3}\right)_{3}(\mathbf{1})$ has two transitions at 360 and $\left.388 \mathrm{~nm}^{[10]}\right\}$. In the visible region, a broad absorbance of low intensity at approx. $550 \mathrm{~nm}$ is also observed for $\mathbf{8}$ and $\mathbf{9}$, and these are assigned to d-d transitions. It is worth noting that the mononuclear $\mathrm{Os}^{\mathrm{III}}$ complex 1, as well as the $\mathrm{Pt}^{\mathrm{II}}$ and $\mathrm{Pd}^{\mathrm{II}}$ complexes $4-6$, have no transitions in this region.

The infrared spectrum of 2,2' -biimidazole shows a strong absorption band at around $3100 \mathrm{~cm}^{-1}$, which is assigned to the $\mathrm{N}-\mathrm{H}$ stretching vibrations. This band is also found in the infrared spectrum of 7 (at $3075 \mathrm{~cm}^{-1}$ ), however, it is not observed in the infrared spectra of $\mathbf{8}$ and $\mathbf{9}$. This implies that complete deprotonation of the $2,2^{\prime}$-biimidazole bridging ligands occurs in the trinuclear compounds 8 and $\mathbf{9}$.

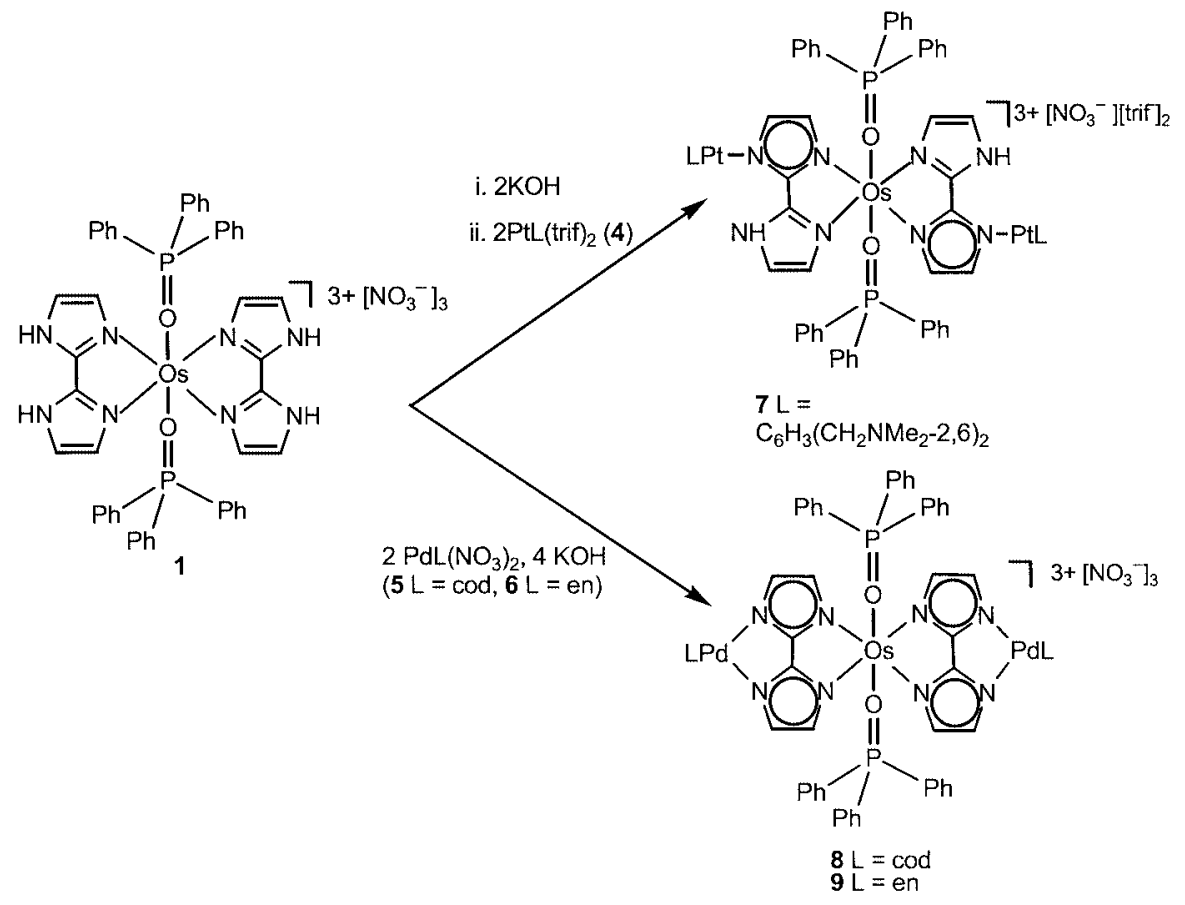

Scheme 1 
The effective magnetic moments of the trinuclear complexes $\left[\mu_{\text {eff }}=1.87(7), 1.45(8), 1.58\right.$ (9) BM; powders, $298 \mathrm{~K}$ ] are as expected for $\mathrm{Os}^{\mathrm{III}}$ complexes (one unpaired electron, $1.73 \mathrm{BM}$ ). Complex 7 could not be characterized by NMR spectroscopy, owing to its magnetic properties. The paramagnetism of complexes $\mathbf{8}$ and $\mathbf{9}$ leads to considerable broadening of the NMR signals, but these spectra are sufficiently resolved to be interpreted. The ${ }^{1} \mathrm{H}$ NMR spectra of $\left[\{\mathrm{Pd}(\operatorname{cod})\}_{2}(\mu \text {-biim })_{2} \mathrm{Os}\left(\mathrm{O}=\mathrm{PPh}_{3}\right)_{2}\right]\left(\mathrm{NO}_{3}\right)_{3} \quad$ (8) and $\left[\{\mathrm{Pd}(\mathrm{en})\}_{2}(\mu \text {-biim })_{2} \mathrm{Os}\left(\mathrm{O}=\mathrm{PPh}_{3}\right)_{2}\right]\left(\mathrm{NO}_{3}\right)_{3}$ (9) show a multiplet between $\delta=7.5$ and $7.8 \mathrm{ppm}$, due to the superimposition of the signals resulting from the $\mathrm{Ph}_{3} \mathrm{PO}$ and biim fragments. The resonance signals at $\delta=2.5$ and $5.5 \mathrm{ppm}$, also observed in the ${ }^{1} \mathrm{H}$ NMR spectrum of $\mathbf{8}$, can be assigned to the $\mathrm{CH}$ and $\mathrm{CH}_{2}$ groups, respectively, of the coordinated cyclooctadiene. They are slightly shifted to a lower field compared to those in the spectrum of the metal-free ligand. In the spectrum of complex $\mathbf{9}$, the resonance signal for the $\mathrm{CH}_{2}$ groups of the en ligands is observed at $\delta=$ $2.96 \mathrm{ppm}$, while in the spectrum of metal-free en, the signal of these protons appears at $\delta=2.85 \mathrm{ppm}$. The carbon resonance signals of the terminal cod $(\delta=28.4,76.4 \mathrm{ppm})$ and en units $(\delta=47.3 \mathrm{ppm})$, observed in the ${ }^{13} \mathrm{C}\left\{{ }^{1} \mathrm{H}\right\}$ NMR spectra of $\mathbf{8}$ and $\mathbf{9}$, respectively, are also shifted to a lower field, when compared with the spectra of the corresponding metal-free ligands. As a result of the deprotonation of $\mathrm{H}_{2}$ biim and the addition of the PdL complex fragments, the ${ }^{13} \mathrm{C}$ resonances of $2,2^{\prime}$-biimidazole are shifted to a lower field in comparison with $\mathbf{1}$. The signal for the $\mathrm{C}$ atoms in the 2, 2'-position is observed at $\delta=$ $152.1 \mathrm{ppm}(\mathbf{8})$ and at $\delta=152.6 \mathrm{ppm}(\mathbf{9})$, while this resonance is found at $\delta=141.2 \mathrm{ppm}$ for $\mathbf{1}$. The variation of the terminal ligand coordinated to the palladium center does not affect the chemical shifts of the $\mathrm{C}$ atoms in the $2,2^{\prime}$ biimidazolate bridging ligands.

In the ${ }^{31} \mathrm{P}\left\{{ }^{1} \mathrm{H}\right\}$ NMR spectra of $\mathbf{8}$ and $\mathbf{9}$, the signal for the phosphorus atom of the triphenylphosphane oxide group is seen at $\delta=32.6 \mathrm{ppm}$. Relative to $\left[\mathrm{Os}\left(\mathrm{H}_{2} \mathrm{bi}-\right.\right.$ $\left.\mathrm{im})_{2}\left(\mathrm{O}=\mathrm{PPh}_{3}\right)_{2}\right]\left(\mathrm{NO}_{3}\right)_{3}$ (1) this ${ }^{31} \mathrm{P}$ signal is shifted to a higher field by approx. $3.8 \mathrm{ppm}$ and this indicates an increase of electron density at the $\mathrm{Os}^{\mathrm{III}}$ center due to better electron donation of the deprotonated 2,2'-biimidazole ligand.

\section{Electrochemistry}

Cyclic voltammetric studies of $\mathbf{1}$ and $\mathbf{7 - 9}$ were carried out in methanol at $25{ }^{\circ} \mathrm{C}$. The mononuclear complex $\left[\mathrm{Os}\left(\mathrm{H}_{2} \text { biim }\right)_{2}\left(\mathrm{O}=\mathrm{PPh}_{3}\right)_{2}\right]\left(\mathrm{NO}_{3}\right)_{3}$ (1) has a reversible oneelectron step at $E_{1 / 2}=-1.01 \mathrm{~V}$ (vs. $\mathrm{FeCp}_{2}{ }^{+} / \mathrm{FeCp}_{2}$, Figure 2, a). This is attributed to the $\mathrm{Os}^{\mathrm{II}} / \mathrm{Os}^{\mathrm{III}}$ redox couple. Complex 1 also has an irreversible $\mathrm{Os}{ }^{\mathrm{III}} / \mathrm{Os}^{\mathrm{IV}}$ oxidation at $0.92 \mathrm{~V}$. In contrast to this, the trinuclear complexes 7-9 have a single quasi-reversible voltammetric response (Figure $2, \mathrm{~b}$ shows the cyclic voltammogram of $\mathbf{8}$ as an example). Since $\left[\mathrm{Pt}\left\{\mathrm{C}_{6} \mathrm{H}_{3}\left(\mathrm{CH}_{2} \mathrm{NMe}_{2}-2,6\right)_{2}\right\}\right]\left(\mathrm{SO}_{3} \mathrm{CF}_{3}\right)$ (4), $\left[\mathrm{Pd}(\mathrm{cod})\left(\mathrm{H}_{2}\right.\right.$ biim $\left.)\right]\left(\mathrm{NO}_{3}\right)_{2}(\mathbf{5})$ and $\left[\mathrm{Pd}(\mathrm{en})\left(\mathrm{H}_{2}\right.\right.$ biim $\left.)\right]\left(\mathrm{NO}_{3}\right)_{2}$ (6) do not have a cyclic voltammetric response in the potential range -1.2 to $+1.2 \mathrm{~V}$, the processes observed in the
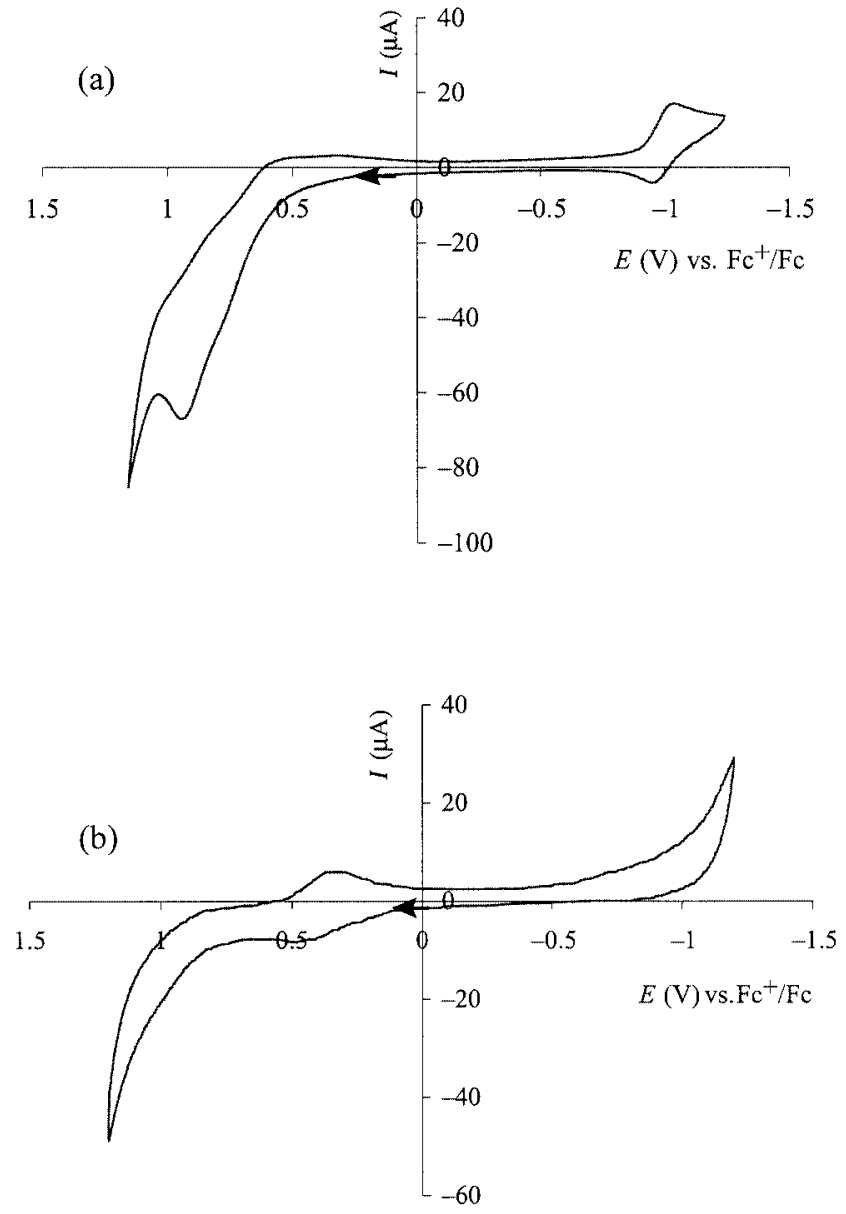

Figure 2. Cyclic voltammograms of (a) $\left[\mathrm{Os}\left(\mathrm{H}_{2} \text { biim }\right)_{2}(\mathrm{O}=\right.$ $\left.\left.\mathrm{PPh}_{3}\right)_{2}\right]\left(\mathrm{NO}_{3}\right)_{3}$ (1) and (b) $\left[\{\mathrm{Pd}(\mathrm{cod})\}_{2} \mathrm{Os}(\mu-\mathrm{biim})_{2}(\mathrm{O}=\right.$ $\left.\left.\mathrm{PPh}_{3}\right)_{2}\right]\left(\mathrm{NO}_{3}\right)_{3}(\mathbf{8})$

cyclic voltammograms of $\mathbf{7 - 9}$ are attributed to the $\mathrm{Os}^{\mathrm{III} /}$ $\mathrm{Os}^{\mathrm{IV}}$ redox couple. Electrochemical data are given in Table 1.

Table 1. Electrochemical data of $\mathbf{1}$ and 7-9

\begin{tabular}{ll}
\hline Complex & \\
\hline$[\mathrm{O}]$ & $E_{1 / 2}\left(\mathrm{Os}_{2}{ }^{\mathrm{III}} / \mathrm{Os}^{\mathrm{IV}}\right)[\mathrm{V}]$ \\
{$\left[\left\{\mathrm{Pt}\left[\mathrm{C}_{6} \mathrm{H}_{3}\left(\mathrm{CH}_{2}\left(\mathrm{O}=\mathrm{PPh}_{3}\right)_{2}\right]\left(\mathrm{NO}_{3}\right)_{3}(\mathbf{1})\right.\right.\right.$} & 0.92 \\
$\left.\left(\mathrm{O}=\mathrm{PPh}_{3}\right)_{2}\right]\left(\mathrm{NO}_{3}\right)\left(\mathrm{SO}_{3} \mathrm{SF}_{3}\right)_{2} \cdot 4 \mathrm{H}_{2} \mathrm{O}(\mathbf{7})$ & 0.53 \\
{$\left[\{\mathrm{Pd}(\mathrm{cod})\}_{2} \mathrm{Os}(\mu-\mathrm{biim})_{2}\left(\mathrm{O}=\mathrm{PPh}_{3}\right)_{2}\right]\left(\mathrm{NO}_{3}\right)_{3}(\mathbf{8})$} & 0.41 \\
{$\left[\{\mathrm{Pd}(\mathrm{en})\}_{2} \mathrm{Os}(\mu-\mathrm{biim})_{2}\left(\mathrm{O}=\mathrm{PPh}_{3}\right)_{2}\right]\left(\mathrm{NO}_{3}\right)_{3}(\mathbf{9})$} & 0.23
\end{tabular}

[a] $\mathrm{CH}_{3} \mathrm{OH}, 25^{\circ} \mathrm{C}$, vs. $E\left(\mathrm{Fc} / \mathrm{Fc}^{+}\right)=0.00 \mathrm{~V}$.

The addition of transition-metal fragments such as $[\operatorname{Pd}(\mathrm{cod})]^{2+}$ or $[\mathrm{Pd}(\mathrm{en})]^{2+}$ to 3 leads to a significant cathodic shift of the Os ${ }^{\mathrm{III}} / \mathrm{Os}^{\mathrm{IV}}$ couple (Table 1). For 9, this occurs at a more negative potential $\left(E_{1 / 2}=+0.23 \mathrm{~V}\right)$ than that for $8\left(E_{1 / 2}=+0.41 \mathrm{~V}\right)$. However, NMR spectroscopy shows that substitution of cod by en in PdL does not affect the chemical shifts of the $\mathrm{C}$ atoms in the biimidazolate bridging 
group, and the chemical shifts of the $\mathrm{P}$ atoms in $\mathrm{Ph}_{3} \mathrm{P}=\mathrm{O}$ in $\mathbf{8}$ and $\mathbf{9}$ are also almost identical. Therefore, it is not appropriate to attribute the difference in the redox potentials of $\mathbf{8}$ and $\mathbf{9}$ to an effect of the terminal ligand (cod, en) on the osmium center. Possible reasons for the shift in the redox potential are a variation of the adsorption properties of the complex cation at the electrode or of the electron transfer between the electrode and the osmium complex as a function of the terminal ligands.

\section{Solid-State Structures}

Slow concentration of dichloromethane/methanol solutions of $\left[\mathrm{Os}(\mathrm{Hbiim})_{2}\left(\mathrm{O}=\mathrm{PPh}_{3}\right)_{2}\right]\left[\mathrm{RhCl}_{4}\left\{\mathrm{NH}\left(\mathrm{CH}_{3}\right)_{2}\right\}_{2}\right]$ (2b) and $\left[\left(\mathrm{Pt}\left\{\mathrm{C}_{6} \mathrm{H}_{3}\left(\mathrm{CH}_{2} \mathrm{NMe}_{2}-2,6\right)_{2}\right\}\right)_{2}(\mu-\mathrm{Hbiim})_{2} \mathrm{Os}\left(\mathrm{O}=\mathrm{PPh}_{3}\right)_{2}\right]-$ $\left(\mathrm{NO}_{3}\right)\left(\mathrm{SO}_{3} \mathrm{CF}_{3}\right)_{2} \cdot 4 \mathrm{H}_{2} \mathrm{O}$ (7) led to the formation of red crystals of $\mathbf{2 b}$ and pale pink crystals of $\mathbf{7}$, respectively. Both $\mathbf{2 b}$ and 7 crystallize in triclinic space groups $P \overline{1}$. The coordination geometry around the osmium center in the two complexes is approximately octahedral. The polyhedron is defined by the four nitrogen atoms of two $\mathrm{Hbiim}^{-}$ligands and the two oxygen atoms of the $\mathrm{Ph}_{3} \mathrm{P}=\mathrm{O}$ units, which are in the axial positions.

Figure 3 shows the ZORTEP ${ }^{[1]}$ plot of complex $\mathbf{2 b}$; structural parameters are given in Table 2. The $[\mathrm{Os}(\mathrm{Hbi}-$ im $\left.)_{2}\left(\mathrm{O}=\mathrm{PPh}_{3}\right)_{2}\right]^{+}$cation and the $\left[\mathrm{RhCl}_{4}\left\{\mathrm{NH}\left(\mathrm{CH}_{3}\right)_{2}\right\}_{2}\right]^{-}$ anion have a center of inversion, located at the osmium and rhodium centers, respectively; the symmetry-generated atoms are identified with the suffix a. The Os(1)-N(1) and Os(1) $-\mathrm{N}(3)$ distances in $\mathbf{2 b}$ (bonds to the mono-deprotonated 2,2'-biimidazolate ligands), are nearly identical to those in $\left[\mathrm{Os}\left(\mathrm{H}_{2} \text { biim }\right)_{2}\left(\mathrm{O}=\mathrm{Ph}_{3}\right)_{2}\right]\left(\mathrm{NO}_{3}\right)_{3}$ (1) [2: $\mathrm{Os}(1)-\mathrm{N}(1)=2.076(2), \operatorname{Os}(1)-\mathrm{N}(3)=2.080(2) ; \mathbf{1}$ : Os $(1)-\mathrm{N}(1)=2.0651(19) \AA^{[10]}$. The deprotonated imidazolate sites in $\mathbf{2 b}$ are trans-oriented. The $\mathrm{Os}(1)-\mathrm{O}(1)$ bond $[2.056(2) \AA]$ is significantly longer than that observed in $\mathbf{1}$ and in other osmium complexes with a triphenylphosphane oxide, e.g., $\left[\mathrm{Os}(\mathrm{OEP})\left(\mathrm{O}=\mathrm{PPh}_{3}\right)_{2}\right](\mathrm{Os}-\mathrm{O}=2.036 \AA$, $\mathrm{OEP}=$ octaethylporphyrin). ${ }^{[12]}$ The bite angle $\mathrm{N}(1)-\mathrm{Os}(1)-\mathrm{N}(3)\left[77.78(6)^{\circ}\right]$ is almost identical to that found in $1\left[77.14(8)^{\circ}\right]$ and is typical for bite angles in biimidazole and biimidazolato transition-metal complexes, e.g., $\quad\left[\mathrm{H}(\mathrm{CO})\left(\mathrm{PPh}_{3}\right)_{2} \mathrm{Ru}(\mu\right.$-biim $\left.) \mathrm{Rh}(\mathrm{cod})\right] \quad[\mathrm{N}-\mathrm{Ru}-\mathrm{N}=$ 79.2(2) $\AA]^{[9]}$ and $\left[\mathrm{OsCl}\left(\eta^{2}-\mathrm{H}_{2}\right)\left(\mathrm{H}_{2} \text { biim }\right)_{2}\left(\mathrm{PiC}_{3} \mathrm{H}_{7}\right)_{2}\right] \mathrm{Cl}$ $\left[\mathrm{N}-\mathrm{Os}-\mathrm{N}=75.6(3)^{\circ}\right] .^{[13]} \mathrm{The}^{\mathrm{R} h^{\mathrm{III}}}$ ion in the counterion $\left[\mathrm{RhCl}_{4}\left(\mathrm{NHMe}_{2}\right)_{2}\right]^{-}$in $\mathbf{2 b}$ has a slightly distorted octahedral coordination geometry, where the chloride ions are situated in the equatorial positions and the amine groups are occupying the axial positions. The $\mathrm{Rh}(1)-\mathrm{Cl}(1)$ [2.3597(5) $\AA$ ] and $\mathrm{Rh}(1)-\mathrm{N}(5)[2.106(2) \AA]$ distances are in agreement with the bond lengths observed in similar octahedral $\mathrm{Rh}^{\mathrm{III}}$ complexes, e.g., $[\mathrm{ImH}]\left[\mathrm{RhCl}_{4}(\mathrm{Im})_{2}\right](\mathrm{Im}=$ imidazole), with $\mathrm{Rh}-\mathrm{Cl}=2.326(2) \AA$ and $\mathrm{Rh}-\mathrm{N}=2.039(4) \AA .{ }^{[14]}$ In the $\left[\mathrm{RhCl}_{4}\left(\mathrm{NHMe}_{2}\right)_{2}\right]^{-}$anion, the four chloride ligands form an almost ideal quadrangle around the $\mathrm{Rh}$ atom $\left[\mathrm{Cl}(1)-\mathrm{Rh}(1)-\mathrm{Cl}(2)=92.979(2)^{\circ}\right]$.

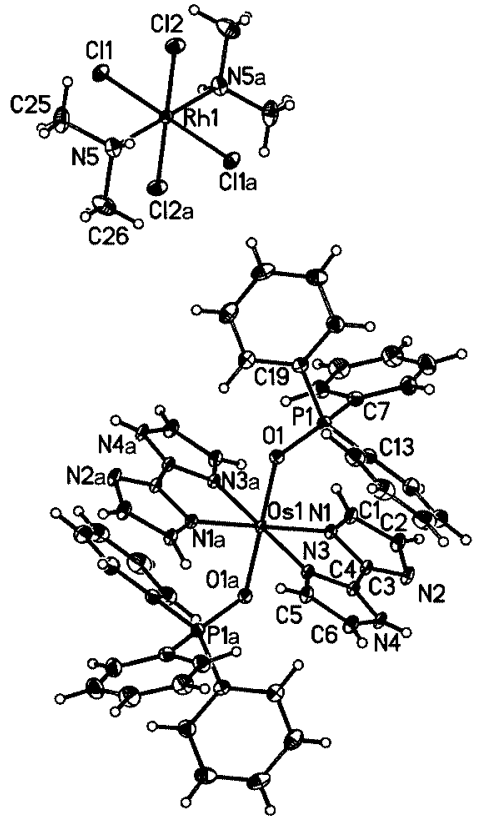

Figure 3. ZORTEP ${ }^{[11]}$ diagram of $\left[\mathrm{Os}(\mathrm{Hbiim})_{2}\left(\mathrm{O}=\mathrm{PPh}_{3}\right)_{2}\right]-$ $\left[\mathrm{RhCl}_{4}\left\{\mathrm{HN}\left(\mathrm{CH}_{3}\right)_{2}\right\}_{2}\right]$ (2b) (50\% probability level); symmetry transformations used to generate equivalent atoms: $a=-x+1,-y+$ $1,-z+1 ; b=-x+2,-y,-z+2$

Table 2. Selected geometric parameters of $\left[\mathrm{Os}(\mathrm{Hbiim})_{2}(\mathrm{O}=\right.$ $\left.\left.\mathrm{PPh}_{3}\right)_{2}\right]\left[\mathrm{RhCl}_{4}\left\{\mathrm{HN}\left(\mathrm{CH}_{3}\right)_{2}\right\}_{2}\right](\mathbf{2 b})$ and $\left[\left(\mathrm{Pt}\left\{\left(\mathrm{NMe}_{2}\right)_{2} \mathrm{CH}_{2}\right\}_{2} \mathrm{C}_{6} \mathrm{H}_{3}\right)_{2}\right.$ $\left.(\mu \text {-Hbiim })_{2} \mathrm{Os}\left(\mathrm{O}=\mathrm{PPh}_{3}\right)_{2}\right]\left(\mathrm{NO}_{3}\right)(\mathrm{OTf})_{2} \cdot 4 \mathrm{H}_{2} \mathrm{O}(7)$

\begin{tabular}{lcc}
\hline & $\mathbf{2 b}$ & $\mathbf{7}$ \\
\hline Distances [A] & & \\
Os1-O1 & $2.056(2)$ & $2.030(5)$ \\
Os1-N1 & $2.076(2)$ & $2.060(5)$ \\
Os1-N3 & $2.080(2)$ & $2.076(5)$ \\
P1-O1 & $1.520(2)$ & $1.513(5)$ \\
N1-C1 & $1.373(3)$ & $1.341(9)$ \\
N1-C3 & $1.367(2)$ & $1.362(6)$ \\
N2-C2 & $1.386(3)$ & $1.380(9)$ \\
N2-C3 & $1.334(2)$ & $1.331(8)$ \\
N3-C4 & $1.350(2)$ & $1.341(8)$ \\
N3-C5 & $1.386(2)$ & $1.386(8)$ \\
N4-C4 & $1.341(2)$ & $1.335(8)$ \\
N4-C6 & $1.382(3)$ & $1.366(9)$ \\
C1-C2 & $1.380(3)$ & $1.376(10)$ \\
C5-C6 & $1.368(3)$ & $1.350(9)$ \\
Pt1-N2 & & $2.130(6)$ \\
Pt1-N5 & & $2.090(6)$ \\
Pt1-N6 & & $2.080(6)$ \\
Pt1-C25 & & $1.949(6)$ \\
Angles [ ${ }^{\circ}$ O & & \\
O1-Os1-N1 & & $92.0(2)$ \\
O1-Os1-N3 & & $95.32(19)$ \\
N1-Os1-N3 & & $78.3(2)$ \\
P1-O1-Os1 & & $147.4(3)$ \\
N2-Pt1-C25 & $97.61(6)$ & $175.2(3)$ \\
N5-Pt1-N6 & $94.38(6)$ & $163.1(2)$ \\
\hline
\end{tabular}

The crystal structure of 7 consists of the trimetallic $\mathrm{OsPt}_{2}$ cation $\left[\left(\mathrm{Pt}\left\{\left(\mathrm{NMe}_{2}\right)_{2} \mathrm{CH}_{2}\right\}_{2} \mathrm{C}_{6} \mathrm{H}_{3}\right)_{2}(\mu-\mathrm{Hbiim})_{2} \mathrm{Os}(\mathrm{O}=\right.$ $\left.\left.\mathrm{PPh}_{3}\right)_{2}\right]^{3+}$ with a nitrate and two triflate counterions and 


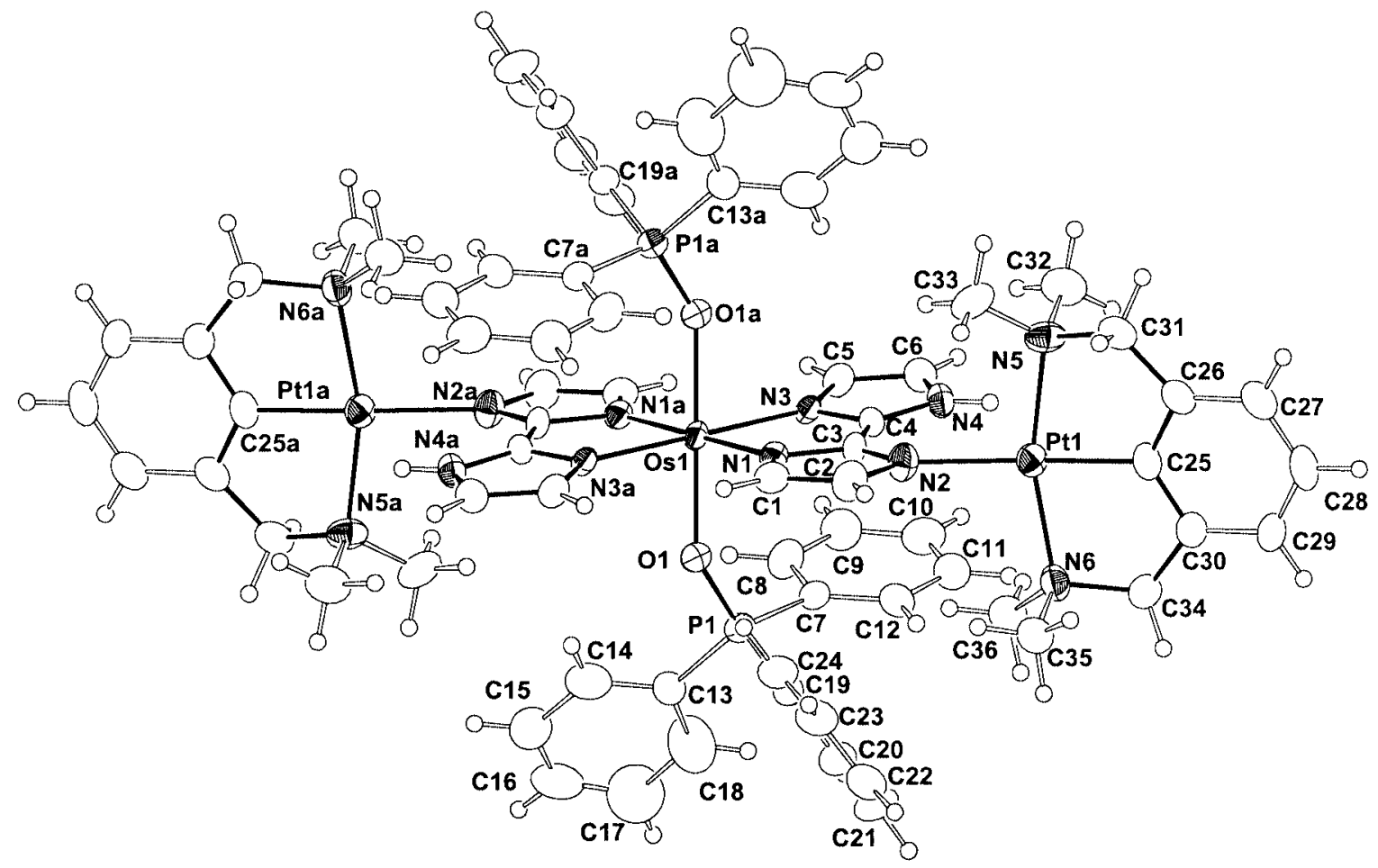

Figure 4. ZORTEP ${ }^{[11]}$ drawing of the complex cation $\left[\left(\mathrm{Pt}\left\{\mathrm{C}_{6} \mathrm{H}_{3}\left(\mathrm{CH}_{2} \mathrm{NMe}_{2}-2,6\right)_{2}\right\}\right)_{2} \mathrm{Os}(\mu-\mathrm{Hbiim})_{2}\left(\mathrm{O}=\mathrm{PPh}_{3}\right)_{2}\right]^{3+}$ of $7(50 \%$ probability level; $\mathrm{NO}_{3}{ }^{-}, \mathrm{SO}_{3} \mathrm{CF}_{3}-$ and $\mathrm{H}_{2} \mathrm{O}$ are omitted for clarity); symmetry transformation used to generate equivalent atoms: $a=-x+1,-y$ $+1,-z ; b=-x+2,-y,-z$

four water molecules in the unit cell. A plot of the molecular cation with the atom numbering scheme is given in Figure 4, selected bond lengths and angles are listed in Table 2 . The molecular cation 7 has a center of inversion situated at the osmium atom; symmetry-generated atoms are identified with the suffix a.

Each Hbiim $^{-}$bridging ligand in 7 is planar [root mean squares deviation $\mathrm{rms}=0.0547 \AA$ ] . The $\mathrm{Os}(1)-\mathrm{N}(1)$ and Os(1) $-\mathrm{N}(2)$ distances are slightly shorter than in $\mathbf{2 b}$, the bite angles of the Os-biim fragment are, as expected, nearly identical to those in $\mathbf{2} \mathbf{b}$. However, some changes are observed in the geometry of the triphenylphosphane oxide ligands. The Os(1)-O(1) distance in 7 is shorter than that in $\mathbf{2 b}$ by $0.026 \AA$, and the $\mathrm{P}(1)-\mathrm{O}(1)-\mathrm{Os}(1)$ angle is larger than that in $\mathbf{2 b}$ by $9.06^{\circ}$. The rigid biimidazole ligand is not affected. The PtL entities are planar $[\mathrm{rms}$ deviation = $0.0389 \AA, \mathrm{Pt}(1)-\mathrm{N}(2)-\mathrm{N}(5)-\mathrm{N}(6)-\mathrm{C}(25)]$ and are trans- disposed, similar to the deprotonated sites in $[\mathrm{Os}(\mathrm{Hbi}-$ im $\left.)_{2}\left(\mathrm{O}=\mathrm{PPh}_{3}\right)_{2}\right]^{+}$in 2b (see Figure 3). The platinum centers have a slightly distorted square-planar coordination geometry. The $\mathrm{N}(5)-\operatorname{Pt}(1)-\mathrm{N}(6)$ angle is $163.1(4)^{\circ}$, which is in the typical range for NCN pincer complexes. ${ }^{[15]}$ The $\mathrm{PtL}$ units are perpendicular to the imidazole rings [interplanar angle between $\mathrm{Pt}(1)-\mathrm{N}(2)-\mathrm{N}(5)-\mathrm{N}(6)-\mathrm{C}(25)$ and $\left.\mathrm{N}(1)-\mathrm{N}(2)-\mathrm{C}(1)-\mathrm{C}(2)-\mathrm{C}(3)=89.14(25)^{\circ}\right]$.

\section{Catalytic Activity}

The catalytic properties of the trimetallic complexes 7-9 were investigated through the homogeneous hydrogenation of 1-hexene and cyclohexene in dichloromethane solutions at $25^{\circ} \mathrm{C}$, and under a hydrogen pressure of 5 bar. The yields of the catalytic hydrogenation reactions are summarized in Table 3. Complex 7, as well as its homodinuclear analog $\left[\left\{\mathrm{Pt}\left(\mathrm{C}_{6} \mathrm{H}_{3}\left(\mathrm{CH}_{2} \mathrm{NMe}_{2}-2,6\right)_{2}\right)\right\}_{2}{ }^{\prime}(\mu-\mathrm{Hbiim})\right]\left(\mathrm{SO}_{3} \mathrm{CF}_{3}\right)_{2}$

Table 3. Homogeneous hydrogenation of 1-hexene and cyclohexene catalyzed by complexes 1, 7-9 and 11

\begin{tabular}{|c|c|c|c|c|}
\hline \multirow[t]{2}{*}{ Catalyst } & \multicolumn{2}{|c|}{ Hydrogenation of 1-hexene } & \multicolumn{2}{|c|}{ Hydrogenation of cyclohexene } \\
\hline & Time $[\mathrm{h}]$ & Yield of hexane $(\%)$ & Time $[\mathrm{h}]$ & Yield of cyclohexane $(\%)$ \\
\hline$\left[\mathrm{Os}\left(\mathrm{H}_{2} \text { biim }\right)_{2}\left(\mathrm{O}=\mathrm{PPh}_{3}\right)_{2}\right]\left(\mathrm{NO}_{3}\right)_{3}(\mathbf{1})$ & 10 & 11 & 10 & 0 \\
\hline$\left[\left(\mathrm{Pt}\left\{\mathrm{C}_{6} \mathrm{H}_{3}\left(\mathrm{CH}_{2} \mathrm{NMe}_{2}-2,6\right)_{2}\right\}\right)_{2}(\mu-\mathrm{Hbiim})\left(\mathrm{SO}_{3} \mathrm{CF}_{3}\right)_{2}(\mathbf{1 1})\right.$ & 5 & 2 & 5 & 3 \\
\hline $\begin{array}{l}{\left[\left(\mathrm{Pt}\left\{\mathrm{C}_{6} \mathrm{H}_{3}\left(\mathrm{CH}_{2} \mathrm{NMe}_{2}-2,6\right)_{2}\right\}\right)_{2}(\mu-\mathrm{Hbiim})_{2} \mathrm{Os}\left(\mathrm{O}=\mathrm{PPh}_{3}\right)_{2}\right]-} \\
\left(\mathrm{NO}_{3}\right)\left(\mathrm{SO}_{3} \mathrm{CF}_{3}\right)_{2} \cdot 4 \mathrm{H}_{2} \mathrm{O}(7)\end{array}$ & 5 & 7 & 5 & 3 \\
\hline$\left[\{\mathrm{Pd}(\mathrm{cod})\}_{2}(\mu-\text { biim })_{2} \mathrm{Os}\left(\mathrm{O}=\mathrm{PPh}_{3}\right)_{2}\right]\left(\mathrm{NO}_{3}\right)_{3}(\mathbf{8})$ & 10 & $53^{[\mathrm{a}]}$ & 10 & 36 \\
\hline$\left[\{\mathrm{Pd}(\mathrm{en})\}_{2}(\mu \text {-biim })_{2} \mathrm{Os}\left(\mathrm{O}=\mathrm{PPh}_{3}\right)_{2}\right]\left(\mathrm{NO}_{3}\right)_{3}(\mathbf{9})$ & 5 & 15 & 5 & 10 \\
\hline
\end{tabular}

[a] By-products: 29\% 2-hexene, 18\% 3-hexene. Note that the formation of by-products in all other experiments was negligible. 
have a low catalytic activity. This is probably due to the inertness of these coordinatively saturated complexes towards ligand exchange. With $\left[\mathrm{Os}\left(\mathrm{H}_{2} \text { biim }\right)_{2}(\mathrm{O}=\right.$ $\left.\left.\mathrm{Ph}_{3}\right)_{2}\right]\left(\mathrm{NO}_{3}\right)_{3}(\mathbf{1})$ as a catalyst, $11 \%$ of hexane was obtained from 1-hexene, but no hydrogenation was observed with cyclohexene. The most active catalyst in the series is $\left[\{\mathrm{Pd}(\mathrm{cod})\}_{2} \mathrm{Os}(\mu \text {-biim })_{2}\left(\mathrm{O}=\mathrm{Ph}_{3}\right)_{2}\right]\left(\mathrm{NO}_{3}\right)_{3}$ (8) (Table 3). A probable mechanism for the catalytic cycle involves hydrogenation of 1,5-cyclooctadiene and the formation of a coordinatively unsaturated palladium center as the catalytically active species. This could explain the lower activity of $\left[\{\mathrm{Pd}(\mathrm{en})\}_{2} \mathrm{Os}(\mu \text {-biim })_{2}\left(\mathrm{O}=\mathrm{PPh}_{3}\right)_{2}\right]\left(\mathrm{NO}_{3}\right)_{3}$ (9) since the chelating ligand en is not easily substituted by substrate molecules. An attempt to use the mononuclear complex $\left[\mathrm{Pd}\left(\mathrm{H}_{2}\right.\right.$ biim $\left.)(\mathrm{cod})\right]\left(\mathrm{NO}_{3}\right)_{2}$ (12) as a homogeneous catalyst under identical conditions was unsuccessful, as it decomposes under hydrogen with the formation of palladium metal. This adequately demonstrates the increased stability of the $\mathrm{Pd}(\mathrm{cod})$ fragment in the trinuclear compound $\mathbf{8}$ relative to the mononuclear precursor $\mathbf{1 2}$.

\section{Conclusions}

Deprotonation of the 2,2'-biimidazole building block in $\left[\mathrm{Os}\left(\mathrm{H}_{2} \text { biim }\right)_{2}\left(\mathrm{O}=\mathrm{PPh}_{3}\right)_{2}\right]\left(\mathrm{NO}_{3}\right)_{3}$ (1) provides a powerful route towards the preparation of the trimetallic $\mathrm{Pt}^{\mathrm{II}}-\mathrm{Os}^{\mathrm{III}}-\mathrm{Pt}^{\mathrm{II}}$ and $\mathrm{Pd}^{\mathrm{II}}-\mathrm{Os}^{\mathrm{III}}-\mathrm{Pd}^{\mathrm{II}}$ complexes 7-9. The solid-state structural analysis of $\left[\left(\mathrm{Pt}\left\{\mathrm{C}_{6} \mathrm{H}_{3}\left(\mathrm{CH}_{2} \mathrm{NMe}_{2^{-}}\right.\right.\right.\right.$ $\left.\left.\left.2,6)_{2}\right\}\right)_{2}(\mu-\mathrm{Hbiim})_{2} \mathrm{Os}\left(\mathrm{O}=\mathrm{PPh}_{3}\right)_{2}\right]\left(\mathrm{NO}_{3}\right)\left(\mathrm{SO}_{3} \mathrm{CF}_{3}\right)_{2} \cdot 4 \mathrm{H}_{2} \mathrm{O}$ (7) demonstrates that the two $\left[\mathrm{Pt}\left\{\mathrm{C}_{6} \mathrm{H}_{3}\left(\mathrm{CH}_{2} \mathrm{NMe}_{2}-2,6\right)_{2}\right\}\right]^{+}$ moieties are trans to each other, as expected from the transdeprotonated sites of the 2,2'-biimidazolato ligands in the starting material, as shown in the solid-state structure of $\left[\mathrm{Os}(\mathrm{Hbiim})_{2}\left(\mathrm{O}=\mathrm{PPh}_{3}\right)_{2}\right]\left[\mathrm{RhCl}_{4}\left\{\mathrm{NH}\left(\mathrm{CH}_{3}\right)_{2}\right\}_{2}\right] \quad$ (2b). Cyclic voltammetric studies demonstrate that deprotonation of 2,2'-biimidazole and the coordination to a second metal ion result in a modification of the redox properties of the central osmium ion, and this is probably due to a change in the ligand field. The $\mathrm{OsPd}_{2}$ complex $\left[\{\mathrm{Pd}(\mathrm{cod})\}_{2}(\mu \text {-biim })_{2-}\right.$ $\left.\mathrm{Os}\left(\mathrm{O}=\mathrm{PPh}_{3}\right)_{2}\right]\left(\mathrm{NO}_{3}\right)_{3} \cdot \mathrm{H}_{2} \mathrm{O}(\mathbf{8})$ is shown to have considerable catalytic activity towards the homogeneous hydrogenation of linear and cyclic alkenes, e.g. 1-hexene and cyclohexene.

\section{Experimental Section}

Materials and Measurements: The complex $\left[\mathrm{Os}\left(\mathrm{H}_{2} \text { biim }\right)_{2}(\mathrm{O}=\right.$ $\left.\left.\mathrm{PPh}_{3}\right)_{2}\right]\left(\mathrm{NO}_{3}\right)_{3} \cdot \mathrm{H}_{2} \mathrm{O} \cdot 0.5 \mathrm{CH}_{3} \mathrm{OH}(\mathbf{1})$ was prepared by a published method. ${ }^{[10]}\left[\mathrm{Os}(\mathrm{Hbiim})_{2}\left(\mathrm{O}=\mathrm{PPh}_{3}\right)_{2}\right]\left(\mathrm{NO}_{3}\right) \cdot 2 \mathrm{H}_{2} \mathrm{O}(2)$ was obtained by reaction of 1 with $\mathrm{KOH}$ in methanol/dichloromethane. ${ }^{[10]}$ $\left[\mathrm{Pt}\left\{\mathrm{C}_{6} \mathrm{H}_{3}\left(\mathrm{CH}_{2} \mathrm{NMe}_{2}-2,6\right)_{2}\right\}\left(\mathrm{H}_{2} \mathrm{O}\right)\right]\left(\mathrm{SO}_{3} \mathrm{CF}_{3}\right)(4)$ was prepared from $\left[\mathrm{Pt}\left\{\mathrm{C}_{6} \mathrm{H}_{3}\left(\mathrm{CH}_{2} \mathrm{NMe}_{2}-2,6\right)_{2}\right\} \mathrm{Cl}\right]^{[15]}$ (addition of $\mathrm{AgSO}_{3} \mathrm{CF}_{3}$ in methanol). $\left[\mathrm{Me}_{2} \mathrm{NH}_{2}\right]\left[\mathrm{RhCl}_{4}\left(\mathrm{HNMe}_{2}\right)_{2}\right]^{[16]}$ was obtained as described elsewhere. ${ }^{1} \mathrm{H},{ }^{13} \mathrm{C}\left\{{ }^{1} \mathrm{H}\right\}$, and ${ }^{31} \mathrm{P}\left\{{ }^{1} \mathrm{H}\right\}$ NMR spectra were recorded with a Bruker AC 250 spectrometer, chemical shifts $\left({ }^{1} \mathrm{H}\right.$ and $\left.{ }^{13} \mathrm{C}\right)$ in ppm are quoted relative to $\mathrm{SiMe}_{4} \cdot{ }^{31} \mathrm{P}$ chemical shifts are given in ppm with respect to $85 \% \mathrm{H}_{3} \mathrm{PO}_{4}\left({ }^{31} \mathrm{P}: \delta=0\right)$ as an external standard. Infrared spectra ( $\mathrm{KBr}$ pellets) were recorded with a Perkin-Elmer 16PC FT-IR instrument. UV/Vis spectra were obtained with a Cary $1 \mathrm{E}$ spectrophotometer. Magnetic measurements were carried out with an Alfa MK 1 magnetic susceptibility balance. Electrochemical measurements $(\mathrm{CV})$ were performed in methanol solutions containing $\left[n \mathrm{Bu}_{4} \mathrm{~N}\right] \mathrm{PF}_{6}\left(0.1 \mathrm{~mol} \cdot \mathrm{dm}^{-3}\right)$ at $293 \mathrm{~K}$, using a BAS 100B system with a glassy carbon working electrode, a platinum auxiliary electrode and an $\mathrm{Ag} / \mathrm{AgCl}$ reference electrode. All potentials are referenced to the ferrocene/ferrocenium couple $(E=0.0 \mathrm{~V})$. GC-MS analyses were performed with a Fison GC 8000/MD 800 series instrument, equipped with a ZB-1 (Zebron) column. Melting (decomposition) points were determined with a Gallenkamp MFB 595010 M melting point apparatus. Organic solvents (methanol, dichloromethane) were freshly distilled before use. Microanalyses were obtained from the microanalytical laboratory of the chemical institutes of the University of Heidelberg or the Technische Universität Bergakademie Freiberg.

X-ray Crystallography: X-ray quality crystals of $\left[\mathrm{Os}(\mathrm{Hbiim})_{2}(\mathrm{O}=\right.$ $\left.\left.\mathrm{PPh}_{3}\right)_{2}\right]\left[\mathrm{RhCl}_{4}\left\{\mathrm{HN}\left(\mathrm{CH}_{3}\right)_{2}\right\}_{2}\right] \quad$ (2b) and $\left[\left(\mathrm{Pt}_{\{} \mathrm{C}_{6} \mathrm{H}_{3}\left(\mathrm{CH}_{2} \mathrm{NMe}_{2}-\right.\right.\right.$ $\left.\left.\left.2,6)_{2}\right\}\right)_{2}(\mu \text {-Hbiim })_{2} \mathrm{Os}\left(\mathrm{O}=\mathrm{PPh}_{3}\right)_{2}\right]\left(\mathrm{NO}_{3}\right)\left(\mathrm{SO}_{3} \mathrm{CF}_{3}\right)_{2}$ (7) were obtained by slow concentration of solutions of the complexes in a dichloromethane/methanol (4:1) mixture at $25^{\circ} \mathrm{C}$. Experimental crystal data are listed in Table 4 and geometric details are presented in Table 2. X-ray structural data were collected with a Bruker SMART CCD diffractometer. The unit cell parameters were checked for the presence of higher lattice symmetry. ${ }^{[17]}$ Data were corrected for absorption using SADABS. ${ }^{[18]}$ The structures were solved by direct methods (SHELX-97/2). ${ }^{[19]}$ Refinement was carried out by full-matrix least-squares techniques on $F^{2}$ (SHELXL97/2). ${ }^{[19]}$ Hydrogen atoms were located from the difference Fourier map. All hydrogen atoms were fully refined. All non-hydrogen atoms were refined anisotropically.

Catalytic Hydrogenation of 1-Hexene and Cyclohexene: All experiments were performed in a $100-\mathrm{mL}$ stainless steal autoclave with an inner polytetrafluorethylene vessel. In a typical experiment, $0.016 \mathrm{mmol}$ of catalyst was placed as a solid in the autoclave, supplied with a magnetic stirring bar. Under stirring, the catalyst was dissolved in $6 \mathrm{~mL}$ of dichloromethane (complexes 7, 8 and 11) or in a mixture $(90: 10,6 \mathrm{~mL})$ of dichloromethane and methanol (complex 9). 1-Hexene or cyclohexene $(0.16 \mathrm{mmol}$; purity checked by GC-MS) was added to the solution of the catalyst. The autoclave was evacuated three times and filled with hydrogen. The pressure of hydrogen was increased to 5 bar. The reaction mixture was stirred for $5 \mathrm{~h}$. The autoclave was then degassed and all volatile materials were evaporated from the reaction mixture using an oilpump vacuum, and condensed (liquid nitrogen). The resulting solution was analyzed by GC-MS.

Synthesis of $\left[\mathrm{Os}(\mathrm{Hbiim})_{2}\left(\mathrm{O}=\mathrm{PPh}_{3}\right)_{2}\right]\left[\mathrm{RhCl}_{4}\left(\mathrm{HNMe}_{2}\right)_{2}\right](\mathbf{2 b})$ : $[\mathrm{Os}(\mathrm{H}-$ biim $\left.)_{2}\left(\mathrm{O}=\mathrm{Ph}_{3}\right)_{2}\right]\left(\mathrm{NO}_{3}\right) \cdot 2 \mathrm{H}_{2} \mathrm{O} \quad(\mathbf{2})^{[10]} \quad(100 \mathrm{mg}, \quad 0.09 \mathrm{mmol})$ was treated with $\left[\mathrm{Me}_{2} \mathrm{NH}_{2}\right]\left[\mathrm{RhCl}_{4}\left(\mathrm{HNMe}_{2}\right)_{2}\right](33 \mathrm{mg}, 0.09 \mathrm{mmol})$ in $20 \mathrm{~mL}$ of a dichloromethane/methanol $(4: 1)$ mixture at $25^{\circ} \mathrm{C}$. Slow evaporation of the solvent resulted in a mixture of solid products. This contained some of the starting materials, $\mathrm{Me}_{2} \mathrm{NH}_{2} \mathrm{NO}_{3}$ and red crystals of $\mathbf{2} \mathbf{b}$, which were hand-picked and suitable for X-ray crystal structural analysis. Due to the very low yield, no further spectroscopic characterization was possible.

Synthesis of $\left[\left(\mathrm{Pt}_{\{}\left\{\mathrm{C}_{6} \mathrm{H}_{3}\left(\mathrm{CH}_{2} \mathrm{NMe}_{2}-2,6\right)_{2}\right\}\right)_{2}(\mu-\mathrm{Hbiim})_{2} \mathrm{Os}(\mathrm{O}=\right.$ $\left.\left.\mathrm{PPh}_{3}\right)_{2}\right]\left(\mathrm{NO}_{3}\right)\left(\mathrm{SO}_{3} \mathrm{CF}_{3}\right)_{2} \cdot \mathbf{4} \mathbf{H}_{2} \mathrm{O} \quad$ (7): $\left[\mathrm{Os}(\mathrm{Hbiim})_{2}\left(\mathrm{O}=\mathrm{Ph}_{3}\right)_{2}\right]-$ $\left(\mathrm{NO}_{3}\right) \cdot 2 \mathrm{H}_{2} \mathrm{O}(2,200 \mathrm{mg}, 0.18 \mathrm{mmol})$ was dissolved at $25{ }^{\circ} \mathrm{C}$ in $15 \mathrm{~mL}$ of a dichloromethane/methanol mixture (4:1). $\left[\mathrm{Pt}\left(\left\{\mathrm{C}_{6} \mathrm{H}_{3}\left(\mathrm{CH}_{2} \mathrm{NMe}_{2}-2,6\right)_{2}\right\}\left(\mathrm{H}_{2} \mathrm{O}\right)\right]\left(\mathrm{SO}_{3} \mathrm{CF}_{3}\right)(199 \mathrm{mg}, 0.36 \mathrm{mmol})\right.$, dissolved in methanol $(5 \mathrm{~mL})$, was added to the solution. The reac- 
Table 4. Crystal data

\begin{tabular}{|c|c|c|}
\hline & $\mathbf{2 b}$ & 7 \\
\hline Empirical formula & $\mathrm{C}_{52} \mathrm{H}_{54} \mathrm{Cl}_{4} \mathrm{~N}_{10} \mathrm{O}_{2} \mathrm{OsP}_{2} \mathrm{Rh}$ & $\mathrm{C}_{74} \mathrm{H}_{86} \mathrm{~F}_{6} \mathrm{~N}_{13} \mathrm{O}_{15} \mathrm{OsP}_{2} \mathrm{Pt}_{2} \mathrm{~S}_{2}$ \\
\hline Formula mass [g/mol] & 1347.90 & 2218.00 \\
\hline Crystal system & triclinic & triclinic \\
\hline Space group & $P \overline{1}$ & $P \overline{1}$ \\
\hline$a[\AA]$ & $10.4293(5)$ & $12.604(3)$ \\
\hline$b[\AA]$ & $10.6365(6)$ & $13.471(3)$ \\
\hline$c[\AA]$ & $13.0287(7)$ & $14.347(3)$ \\
\hline$\alpha\left[^{\circ}\right]$ & $102.928(1)$ & $63.919(4)$ \\
\hline$\beta\left[^{\circ}\right]$ & $91.684(1)$ & $77.530(5)$ \\
\hline$\gamma\left[{ }^{\circ}\right]$ & $109.854(1)$ & $66.613(4)$ \\
\hline$V\left[\mathrm{~A}^{3}\right]$ & $1316.1(1)$ & $2005.6(7)$ \\
\hline$Z^{2-1}$ & 1 & 1 \\
\hline$T[\mathrm{~K}]$ & $103(2)$ & $173(2)$ \\
\hline Radiation used $(\lambda[\AA])$ & Mo- $K_{\alpha}(0.70173)$ & Mo- $K_{\alpha}(0.70173)$ \\
\hline Reflection collected & 22971 & 16683 \\
\hline Independent reflection & 8886 & 11171 \\
\hline$R$ (int) & 0.0287 & 0.428 \\
\hline Linear absorption coefficient $\left[\mathrm{mm}^{-1}\right]$ & 3.040 & 5.237 \\
\hline$R^{[\mathrm{a}]}[I>2 \sigma(I)] /$ all & $0.0238 / 0.0275$ & $0.0487 / 0.1043$ \\
\hline$w R 2^{[\mathrm{b}]}[I>2 \sigma(I)] /$ all & $0.0567 / 0.0592$ & $0.1008 / 0.1191$ \\
\hline Goodness-of-fit on $F^{2}$ & 1.055 & 0.958 \\
\hline
\end{tabular}

${ }^{[\mathrm{a}]} R=\Sigma|| F_{\mathrm{o}}|-| F_{\mathrm{c}}|/ / \Sigma| F_{\mathrm{o}} \mid \cdot{ }^{[\mathrm{b}]} w R 2=\left[\Sigma\left[w\left(F_{\mathrm{o}}{ }^{2}-F_{\mathrm{c}}{ }^{2}\right)^{2}\right] / \Sigma w\left(F_{\mathrm{o}}{ }^{4}\right)\right]^{1 / 2}$.

tion mixture immediately changed from violet to red. The solution was stirred for $2 \mathrm{~h}$, after which the volume was reduced to $4 \mathrm{~mL}$. After $10 \mathrm{~h}$ at $25^{\circ} \mathrm{C}$, pale pink crystals of 7 precipitated. The slurry was decanted and the crystalline precipitate was washed twice with acetone $(5 \mathrm{~mL})$ and dried using an oil-pump vacuum to afford analytically pure 7. Yield: $290 \mathrm{mg}(0.13 \mathrm{mmol}, 73 \%$ based on 2). M.p. $219{ }^{\circ} \mathrm{C}$ (dec.). IR $\left(\mathrm{KBr}, \mathrm{cm}^{-1}\right): \tilde{v}=1130 v_{(\mathrm{P}=\mathrm{O})}, 1276 v_{(\mathrm{S}=\mathrm{O})}, 1385$ $v_{\mathrm{a}\left(\mathrm{NO}^{3-}\right)}, 1439 v_{(\mathrm{Ar}, \mathrm{C}=\mathrm{C})}, 3075 v_{(\mathrm{NH})}$. Due to paramagnetic line broadening no NMR spectra were recorded [molar magnetic susceptibility (powder, $298 \mathrm{~K}$ ): $1.49 \times 10^{-3} \mathrm{~cm}^{3} \cdot \mathrm{mol}^{-1}$ ]. UV/Vis $\left(\mathrm{CH}_{2} \mathrm{Cl}_{2}\right): \lambda_{\max }\left(\varepsilon, \mathrm{mol}^{-1} \cdot \mathrm{dm}^{3} \cdot \mathrm{cm}^{-1}\right)=548\left(6.2 \times 10^{2}\right), 375 \mathrm{~nm}(\mathrm{sh}$, $\left.7.4 \times 10^{3}\right) . \mathrm{CV}\left(\mathrm{CH}_{3} \mathrm{OH}, 25^{\circ} \mathrm{C}\right): E_{1 / 2}\left(\mathrm{Os}^{\mathrm{III}} / \mathrm{Os}^{\mathrm{IV}}\right)=+0.53 \mathrm{~V}(\Delta E=$ $200 \mathrm{mV}$ ). $\mathrm{C}_{74} \mathrm{H}_{86} \mathrm{~F}_{3} \mathrm{~N}_{13} \mathrm{O}_{15} \mathrm{OsP}_{2} \mathrm{Pt}_{2} \mathrm{~S}_{2}$ (2218.00): calcd. C 40.07, H 3.91, N 8.21; found C 40.04, H 3.85, N 8.47.

Synthesis of $\left[\{\mathrm{Pd}(\mathrm{cod})\}_{2}(\mu \text {-biim })_{2} \mathrm{Os}\left(\mathrm{O}=\mathrm{PPh}_{3}\right)_{2}\right]\left(\mathrm{NO}_{3}\right)_{3} \cdot \mathbf{2 H}_{2} \mathrm{O}$ (8): $\left[\mathrm{Os}\left(\mathrm{H}_{2} \text { biim }\right)_{2}\left(\mathrm{O}=\mathrm{Ph}_{3}\right)_{2}\right]\left(\mathrm{NO}_{3}\right)_{3} \quad(\mathbf{1}, \quad(247 \mathrm{mg}, 0.2 \mathrm{mmol})$ was dissolved in dichloromethane/methanol $(4: 1,20 \mathrm{~mL})$ at $25^{\circ} \mathrm{C}$. Potassium hydroxide $(4.0 \mathrm{~mL}, 0.2 \mathrm{M}$ in $\mathrm{MeOH})$ was added. After stirring at room temperature for $15 \mathrm{~min},\left[\mathrm{Pd}\left(\mathrm{NO}_{3}\right)_{2}(\mathrm{cod})\right]\{0.40 \mathrm{mmol}$, prepared in situ by the reaction of $\left[\mathrm{PdCl}_{2}(\mathrm{cod})\right](120 \mathrm{mg}, 0.42 \mathrm{mmol})$ with $\mathrm{AgNO}_{3}$ (143 mg, $\left.\left.0.84 \mathrm{mmol}\right)\right\}$ was added. The reaction mixture was stirred for $1 \mathrm{~h}$. All volatile products were then removed using an oil-pump vacuum, and the remaining residue was extracted with dichloromethane $(100 \mathrm{~mL})$. The extract was filtered and dichloromethane was removed using an oil-pump vacuum to afford 8 as a dark green solid. Yield: $295 \mathrm{mg}(0.178 \mathrm{mmol}$, $89 \%$ based on 1). M.p.: gradual decomposition at $>150{ }^{\circ} \mathrm{C}$. IR $(\mathrm{KBr}$, $\left.\mathrm{cm}^{-1}\right): \tilde{v}=1120 \mathrm{v}_{(\mathrm{P}=\mathrm{O})}, 1184 \mathrm{v}_{\mathrm{a}\left(\mathrm{NO}^{3-}\right)}, 1436 \mathrm{v}_{(\mathrm{Ar}, \mathrm{C}=\mathrm{C})} \cdot{ }^{1} \mathrm{H} \mathrm{NMR}$ $\left(\mathrm{CD}_{3} \mathrm{OD}\right.$ ): $\delta=2.5$ (br. s, $16 \mathrm{H}, \mathrm{CH}_{2}$, cod), 5.5 (br. s, $8 \mathrm{H}, \mathrm{CH}$, cod), 7.5-7.8 (m, $34 \mathrm{H}, \mathrm{C}_{6} \mathrm{H}_{5}, \mathrm{H}_{2}$-bim) ppm. ${ }^{13} \mathrm{C}\left\{{ }^{1} \mathrm{H}\right\} \mathrm{NMR}$ $\left(\mathrm{CD}_{3} \mathrm{OD}\right): \delta=28.4\left(\mathrm{CH}_{2}, \mathrm{cod}\right), 76.4(\mathrm{CH}, \operatorname{cod}), 129.9\left(\mathrm{C}-2,-2^{\prime}\right.$, biim $\left.^{2-}\right), 130.1\left(\mathrm{CH}, \mathrm{C}_{6} \mathrm{H}_{5}\right), 133.1\left(\mathrm{CH}, \mathrm{C}_{6} \mathrm{H}_{5}\right), 133.8\left(\mathrm{CH}, \mathrm{C}_{6} \mathrm{H}_{5}\right)$, $136.4\left(i-\mathrm{C}, \mathrm{C}_{6} \mathrm{H}_{5}\right), 141.3\left(\mathrm{C}-5,-5^{\prime}\right.$, biim $\left.^{2-}\right), 152.1\left(\mathrm{C}-4,4^{\prime}\right.$, biim $\left.^{2-}\right)$ ppm. ${ }^{31} \mathrm{P}\left\{{ }^{1} \mathrm{H}\right\}$ NMR $\left(\mathrm{CD}_{3} \mathrm{OD}\right): \delta=32.6 \mathrm{ppm}$. Molar magnetic susceptibility (powder, $298 \mathrm{~K}$ ): $8.84 \times 10^{-4} \mathrm{~cm}^{3} \cdot \mathrm{mol}^{-1}$. UV/Vis $\left(\mathrm{CH}_{2} \mathrm{Cl}_{2}\right): \lambda_{\max }\left(\varepsilon, \mathrm{L} \cdot \mathrm{cm}^{-1} \cdot \mathrm{mol}^{-1}\right)=351\left(7.7 \times 10^{3}\right), 548 \mathrm{~nm}$ $\left(3.9 \times 10^{3}\right) . \mathrm{CV}\left(\mathrm{CH}_{3} \mathrm{OH}\right): E_{1 / 2}\left(\mathrm{Os}^{\mathrm{IV}} / \mathrm{Os}^{\mathrm{III}}\right)=+0.41 \mathrm{~V}(\Delta E=280$
$\mathrm{mV}) . \mathrm{C}_{64} \mathrm{H}_{66} \mathrm{~N}_{11} \mathrm{O}_{13} \mathrm{OsP}_{2} \mathrm{Pd}_{2}$ (1662.28): calcd. C 46.24, $\mathrm{H} 4.00, \mathrm{~N}$ 9.27; found C 45.81, H 4.16, N 9.25.

Synthesis of $\left[\{\mathrm{Pd}(\mathrm{en})\}_{2}(\mu \text {-biim })_{2} \mathrm{Os}\left(\mathrm{O}=\mathrm{PPh}_{3}\right)_{2}\right]\left(\mathrm{NO}_{3}\right)_{3} \cdot \mathrm{H}_{2} \mathrm{O}$ (9): This complex was prepared from $\mathbf{1}(250 \mathrm{mg}, 0.202 \mathrm{mmol})$ and $\left[\mathrm{Pd}(\mathrm{en})\left(\mathrm{H}_{2} \mathrm{O}\right)_{2}\right]\left(\mathrm{NO}_{3}\right)_{2}(132 \mathrm{mg}, 0.404 \mathrm{mmol})$, according to a procedure identical to that for $\mathbf{8}$. A dark green solid was isolated. Yield: $270 \mathrm{mg}$ ( $0.174 \mathrm{mmol}, 87 \%$ based on 1). M.p.: gradual decomposition at $>150{ }^{\circ} \mathrm{C}$. IR $\left(\mathrm{KBr}, \mathrm{cm}^{-1}\right): \tilde{v}=1118 v_{(\mathrm{P}=\mathrm{O})}, 1384$ $\left.v_{\mathrm{a}\left(\mathrm{NO}^{3-}\right.}{ }^{3-}\right), 1438 v_{(\mathrm{Ar}, \mathrm{C}=\mathrm{C})} \cdot{ }^{1} \mathrm{H} \mathrm{NMR}\left(\mathrm{CD}_{3} \mathrm{OD}\right): \delta=2.96$ (br. $\mathrm{s}, 8 \mathrm{H}$, $\mathrm{CH}_{2}$, en), 7.6-7.8 (m, $34 \mathrm{H}, \mathrm{C}_{6} \mathrm{H}_{5}, \mathrm{H}_{2}$ bim) ppm. ${ }^{13} \mathrm{C}\left\{{ }^{1} \mathrm{H}\right\} \mathrm{NMR}$ $\left(\mathrm{CD}_{3} \mathrm{OD}\right): \delta=47.3\left(\mathrm{CH}_{2}\right.$, en $), 129.9\left(\mathrm{C}-2,-2^{\prime}\right.$, biim $\left.^{2-}\right), 130.0(\mathrm{CH}$, $\left.\mathrm{C}_{6} \mathrm{H}_{5}\right), 133.1\left(\mathrm{CH}, \mathrm{C}_{6} \mathrm{H}_{5}\right), 133.8\left(\mathrm{CH}, \mathrm{C}_{6} \mathrm{H}_{5}\right), 136.7\left(i-\mathrm{C}, \mathrm{C}_{6} \mathrm{H}_{5}\right)$, 141.1 (C-5,-5', biim $\left.{ }^{2-}\right), 152.6\left(\mathrm{C}-4,4^{\prime}\right.$, biim $\left.^{2-}\right)$ ppm. ${ }^{31} \mathrm{P}\left\{{ }^{1} \mathrm{H}\right\}$ NMR $\left(\mathrm{CD}_{3} \mathrm{OD}\right): \delta=32.6 \mathrm{ppm}$. Molar magnetic susceptibility (powder, $298 \mathrm{~K}): \quad 1.07 \times 10^{-3} \mathrm{~cm}^{3} \cdot \mathrm{mol}^{-1}$. UV/Vis $\left(\mathrm{CH}_{2} \mathrm{Cl}_{2}\right): \lambda_{\max }(\varepsilon$, $\left.\mathrm{L} \cdot \mathrm{cm}^{-1} \cdot \mathrm{mol}^{-1}\right)=347\left(7.1 \times 10^{3}\right), \quad 547 \mathrm{~nm} \quad\left(2.7 \times 10^{3}\right) . \quad \mathrm{CV}$ $\left(\mathrm{CH}_{3} \mathrm{OH}\right): \quad E_{1 / 2}\left(\mathrm{Os}^{\mathrm{IV}} / \mathrm{Os}^{\mathrm{III}}\right)=+0.23 \mathrm{~V}(\Delta E=390 \mathrm{mV})$. $\mathrm{C}_{52} \mathrm{H}_{56} \mathrm{~N}_{15} \mathrm{O}_{12} \mathrm{OsP}_{2} \mathrm{Pd}_{2}$ (1548.10): calcd. C 40.34, H 3.65, N 13.57; found $\mathrm{C} 40.48, \mathrm{H} 3.72, \mathrm{~N} 13.15$.

Synthesis of $\left[\left\{\mathrm{Pt}\left(\mathrm{C}_{6} \mathrm{H}_{3}\left(\mathrm{CH}_{2} \mathrm{NMe}_{2}-2,6\right)_{2}\right)\right\}_{2}\left(\mu-\mathrm{H}_{2} \mathrm{biim}\right)\right]\left(\mathrm{SO}_{3} \mathrm{CF}_{3}\right)_{2}$ (11): $\left[\mathrm{Pt}\left(\mathrm{C}_{6} \mathrm{H}_{3}\left(\mathrm{CH}_{2} \mathrm{NMe}_{2}-2,6\right)_{2}\right) \mathrm{Cl}\right]^{[15]}(100 \mathrm{mg}, 0.24 \mathrm{mmol})$ was dissolved in methanol $(20 \mathrm{~mL})$ and treated with $\mathrm{AgOSO}_{2} \mathrm{CF}_{3}(61 \mathrm{mg}$, $0.24 \mathrm{mmol})$. The reaction mixture was stirred for $12 \mathrm{~h}$ and $\mathrm{AgCl}$ was removed by filtration $2,2^{\prime}$ Biimidazole $(16 \mathrm{mg}, 0.12 \mathrm{mmol}$ ) was added to the filtrate and the reaction mixture was stirred for $10 \mathrm{~h}$. After filtration, methanol was removed using an oil-pump vacuum to afford 11 as a gray solid. Yield: $120 \mathrm{mg}\{0.1 \mathrm{mmol}, 84 \%$ based on $\left.\left[\mathrm{Pt}\left(\mathrm{C}_{6} \mathrm{H}_{3}\left(\mathrm{CH}_{2} \mathrm{NMe}_{2}-2,6\right)_{2}\right) \mathrm{Cl}\right]\right\}$. M.p. $214{ }^{\circ} \mathrm{C}$ (dec.). IR $\left(\mathrm{KBr}, \mathrm{cm}^{-1}\right): \tilde{v}=1275 \mathrm{v}_{(\mathrm{S}=\mathrm{O})}, 1441 \mathrm{v}_{(\mathrm{Ar}, \mathrm{C}=\mathrm{C})}, 3080 \mathrm{v}_{(\mathrm{NH})}$. $\mathrm{C}_{32} \mathrm{H}_{44} \mathrm{~F}_{6} \mathrm{~N}_{8} \mathrm{O}_{6} \mathrm{Pt}_{2} \mathrm{~S}_{2}$ (1205.02): calcd. C 31.90, H 3.68, N 9.30; found $\mathrm{C} 31.52, \mathrm{H} 4.05, \mathrm{~N} 8.95$.

\section{Acknowledgments}

This work was supported in part by the Deutsche Forschungsgemeinschaft, the Fond der Chemischen Industrie and the 
Alexander-von-Humboldt-Stiftung. We thank Mrs. Petra Krämer for help in performing the GC-MS analyses. We also would like to thank Degussa AG (Hanau) for the generous gift of $\mathrm{OsO}_{4}$ and $\mathrm{RhCl}_{3}$.

[1] [1a] R. Choukroun, D. Gervais, P. Kalck, F. Senocq, J. Organomet. Chem. 1987, 335, C9-C12. ${ }^{[\mathrm{b}]} \mathrm{R}$. Mutin, C. Lucas, J. Thivole-Cazat, V. Dufand, F. Dany, J. M. Basset, J. Chem. Soc., Chem. Commun. 1988, 896-898. [1c] M. A. Esteruelas, M. P. Garcia, A. M. Lopez, L. Oro, Organometallics 1991, 10, 127-133. ${ }^{[1 \mathrm{~d}]}$ E. Sola, V. I. Bakhmutov, F. Torres, A. Elduque, J. A. Lopez, F. Lahoz, H. Werner, L. A. Oro, Organometallics 1998, 17, 683-696.

${ }^{[2]}{ }^{[2 a]}$ P. Kalck, Polyhedron 1988, 7, 2441-2450. ${ }^{[2 b]}$ A. Dedieu, P. Escaffre, J. M. Frances, P. Kalk, A. Thorez, Nouv. J. Chem. 1986, 10, 631-696.

[3] [3a] S. W. Kaiser, R. B. Saillant, W. M. Butler, P. G. Rasmussen, Inorg. Chem. 1976, 15, 2681-2687. ${ }^{[3 b]} \mathrm{S}$. W. Kaiser, R. B. Saillant, P. G. Rasmussen, J. Am. Chem. Soc. 1975, 97, 425-426. ${ }^{[3 c]}$ S. W. Kaiser, R. B. Saillant, W. M. Butler, P. G. Rasmussen, Inorg. Chem. 1976, 15, 2688-2694.

[4] M. S. Haddad, D. N. Hendrickson, Inorg. Chem. 1978, 17, $2622-2630$

[5] R. Usón, J. Gimeno, J. Forniés, F. Martínez, Inorg. Chim. Acta 1981, 50, 173-177.

[6] A. Maiboroda, G. Rheinwald, H. Lang, Inorg. Chem. Commun. 2001, 4, 381-383.
[7] P. Majumdar, S.-M. Peng, S. Goswami, J. Chem. Soc., Dalton Trans. 1998, 1569-1574.

${ }^{[8]}$ M. P. Garcia, A. M. López, M. A. Esteruelas, F. J. Lahoz, L. A. Oro, Chem. Commun. 1988, 793-795.

[9] R. Usón, L. A. Oro, J. Gimeno, M. A. Ciriano, J. A. Cabeza, J. Chem. Soc., Dalton. Trans. 1983, 233-230.

[10] A. Maiboroda, G. Rheinwald, H. Lang, Eur. J. Inorg. Chem. 2001, 2263-2269.

${ }^{[11]}$ L. Zsolnai, G. Huttner, ZORTEP, University of Heidelberg, 1994.

${ }^{[12]}$ C. M. Che, T. F. Lai, W. C. Chung, W. F. Schaefer, H. B. Grey, Inorg. Chem. 1987, 26, 3907-3911.

${ }^{[13]}$ M. A. Esteruelas, F. J. Lahoz, L. A. Oro, E. Onate, N. Ruiz, Inorg. Chem. 1994, 33, 787-792.

${ }^{[14]}$ G. Mesroni, E. Alessio, A. Sessanta o Santi, S. Geremia, A. Bergamo, G. Sava, A. Boccarelli, A. Schettino, M. Coluccia, Inorg. Chim. Acta 1998, 273, 62-71.

${ }^{[15]}$ J. Terheijden, G. Van Koten, F. Muller, D. M. Grove, K. Vrieze, E. Nielsen, C. H. Stam, J. Organomet. Chem. 1986, 315, 401-417.

${ }^{[16]}$ I. B. Bondarenko, N. A. Buzina, Yu. S. Varshavskii, M. I. Gel'fman, V. V. Razumovskii, T. G. Cherkasova, Russ. J. Inorg. Chem. 1971, 16, 1629-1672.

${ }^{[17]}$ A. L. Spek, Acta Crystallogr., Sect. A 1990, 46, C34

${ }^{[18]}$ Area-Detector Absorption Corrections, Siemens Industrial Automation, Inc., Madison, WI, 1996.

${ }^{[19]}$ G. M. Sheldrick, SHELX-97, Programs for Crystal Structure Analysis (Release 97-2), University of Göttingen, Germany, 1997.

Received October 9, 2002 